\title{
Beneficial Management Practices on Growth and Yield Parameters of Maize (Zea mays) and Soil Fertility Improvement
}

\author{
J.A.S. Chathurika* , S.P. Indraratne ${ }^{1}$, W.S. Dandeniya ${ }^{1}$ and D. Kumaragamage ${ }^{2}$ \\ Postgraduate Institute of Agriculture \\ University of Peradeniya \\ Sri Lanka
}

\begin{abstract}
Beneficial management practices can be used to improve the crop productivity of tropical Alfisols. This study evaluated beneficial management practices to overcome the soil physical and chemical limitations for growing maize (Zea mays). The experiment was conducted in the Low Country Dry Zone (DL1b) on Reddish Brown Earth soil (Typic Rhodustalf). Four treatments; un-amended control (C), site specific fertilizer (SSF), biochar applied at $1 \mathrm{t} / \mathrm{ha}$ with SFF $(\mathrm{BC}+\mathrm{SSF})$ and rock powder applied at $10 \mathrm{t} / \mathrm{ha}$ with SSF (RP+SSF) were tested using maize as the test crop initially in the greenhouse and later in the field at DL1b for two growing seasons (2013 Yala and 2013/2014 Maha) for their effects on crop growth and soil fertility. Soil was neutral, non-saline, sandy clay loam in texture with comparatively high clay content $(27 \%)$ and low in organic matter content $(1.5 \%)$ and deficient in $\mathrm{N}, \mathrm{P}, \mathrm{S}, \mathrm{Ca}, \mathrm{Zn}$, and $\mathrm{Cu}$, initially. In the greenhouse, plant dry weight increased significantly with the addition of amendments i.e., fertilizers alone (SSF), or $\mathrm{BC}+\mathrm{SSF}$ or RP+SSF. In the field study, no significant differences were observed for soil $\mathrm{pH}$ with the addition of amendments but biochar application significantly increased cation exchange capacity, organic matter, potentially mineralizable nitrogen and carbon management index. Rock powder+SSF and $\mathrm{BC}+\mathrm{SSF}$ significantly increased the grain yield over the control in both seasons. Both labile and recalcitrant $C$ were significantly higher in $\mathrm{BC}+\mathrm{SSF}$ treatment than the others. Further, application of BC and RP had no significant impact on soil textural fractions and bulk density, yet in both seasons, BC+SSF application increased the aggregate stability greater than other treatments. The results of the field experiment suggest that biochar and rock powder with adequate nutrients effectively improved soil fertility and productivity.
\end{abstract}

Keywords: biochar, nutrient management, rock powder

\section{INTRODUCTION}

Sri Lankan soils are generally low in soil fertility and high inputs are needed for crop production. Oldeman (1994) indicates that world's agricultural lands are degraded as a result of atmospheric and water pollution, extensive cultivation, over-grazing, and land clearing like activities leading to salinization, soil erosion, and desertification. The impact of modern farming practices on nutrient depletion (Gillingham and Thorrold, 2000) and soil quality (Liebig and Doran, 1999) has been a concern for scientists around the world. The effects of management practices on soil fertility has been studied by evaluating the changes in soil

Department of Soil Science, Faculty of Agriculture, University of Peradeniya, Peradeniya, Sri Lanka.

Department of Environmental Studies and Sciences, University of Winnipeg, MB, Canada

Corresponding author: email-suranichathurika@yahoo.com 
carbon pool (lability and size of different carbon pools), soil reaction, aggregate stability, nutrient supplying capacity (nutrient availability and retention) like characters (Tisdall and Oadas 1983, Sikora et al., 1996; Weil et al., 2003; Milton da Veiga et al., 2008). The beneficial management practices such as application of organic materials, crop rotations and tillage practices are known for improving the soil physical, chemical and biological properties (Milton da Veiga et al., 2008).

The use of mineral fertilizers in a balanced manner to supply nutrients and application of organic amendments for enriching soil organic carbon are two practices that could improve soil fertility. Problems linked to soil physical properties such as excessive or poor drainage, high erodability and compaction cannot be solved easily yet severely affect yield (Adeoye and Mohamed-Saleem, 1990; Akinci et al., 2004). Organic matter application is known to improve soil tillth even in compacted layers (Ekwue and Stone, 1995). Application of rock powder or sand to soil is not new because rock powder has been used as a soil amendment to tackle various soil constraints previously (Silva et al., 2013; Gillman et al., 2002).

Since soil fertility parameters could be highly spatially variable, soil fertility constraints could be site specific. Identification of those site specific fertility constraints and correcting them by beneficial soil management practices are important for improving crop production. Soil amendments used in beneficial soil management should be specifically selected considering site specific soil fertility constraints. The objective of this study was to evaluate beneficial management practices for improving soil fertility and maize yield in a tropical Alfisol.

\section{METHODOLOGY}

\section{Study site, soil analysis and analysis of amendments}

Experiments were conducted at Field Crop Research and Development Institute Mahailluppallama $\left(8^{0} 6.6^{\prime} \mathrm{N} 80^{\circ} 27.8^{\prime} \mathrm{E}\right)$, at low country dry zone (DL1b) where soil is Reddish Brown Earth (RBE: Typic Rhodustalfs) (De Silva and Dassanayake, 2010). A low productive field was selected by the available farm records. A representative composite soil sample was collected at $0-15 \mathrm{~cm}$ for soil determining initial soil conditions.

Basic soil properties and available nutrients were analysed as described below. Soil $\mathrm{pH}$ and electrical conductivity (EC) (1:2.5 soil: solution) were measured using pH meter (EuTech model 510) and conductivity meter (EuTech), respectively. Cation Exchange Capacity (CEC) was determined using $\mathrm{NH}_{4} \mathrm{OAC}$ buffer solution at $\mathrm{pH} 7$ (Summer and Miller, 1996). Organic carbon (OC) contents of the soils were determined by digestion with an acid dichromate solution and titrating with ferrous ammonium sulphate according to modified Walkley and Black method (Nelson and Sommer, 1996) and converted into soil organic matter (OM) content using the Van Bemmelen factor of 1.72. Apparent fixed carbon (FC) in the biochar was measured by dry combustion method using muffle furnace (Enders et al., 2012). Soil texture was determined by pipette method (Gee and Dani, 2000). Available nutrients were extracted by three step extraction procedure described by Portch and Hunter (2002) and evaluated by Kumaragamage and Indraratne (2011) for Sri Lankan soils. Particle size distribution of amendments were analysed before sieving them by $2 \mathrm{~mm}$ sieve (Gee and Dani, 2000). The potentially mineralizable nitrogen was analyzed on field moist soil by estimating the rate of $\mathrm{NH}_{4}-\mathrm{N}$ produced from waterlogged incubation method as described by Keeney (1982). Ammonium-N was extracted using $2 \mathrm{M} \mathrm{KCl}$ and ammonium concentration 
was measured colourimetrically in $680 \mathrm{~nm}$. Permanganate oxidizable carbon (POXC) was determined following Weil et al. (2003). Method in brief, soil was shaken for 2 min with $0.02 \mathrm{M} \mathrm{KMnO}_{4}$ solution and sample was centrifuged for $5 \mathrm{~min}$. The absorbance of the purple colour of the supernatant was measured by UV visible spectrophotometer at $550 \mathrm{~nm}$ wave length. Using the POXC data and organic carbon data, carbon pool index (CPI), the Lability index (LI) and carbon management index (CMI) were calculated. Carbon values determined for soil only treatment (control) were used as the reference values in the calculations.

$$
\begin{aligned}
& \text { C pool Index }(\mathrm{CPI})=\frac{\text { Sample total } \mathrm{C}}{\text { Reference total C }} \\
& \text { Lability of } \mathrm{C}(\mathrm{L})=\frac{\mathrm{C} \text { in fraction oxidized by KMn } 04}{\mathrm{C} \text { remainning unoxidizes by KMnO4 }} \\
& \text { Lability index }(\mathrm{LI})=\frac{\text { Lability of the C in sample }}{\text { Lability of C in reference }} \\
& \text { Carbon management index }(\mathrm{CMI})=\mathrm{CPI} \times \mathrm{LI} \times 100
\end{aligned}
$$

Soil bulk density was measured using the soil core method (Blake and Hartge, 1986). Wet aggregate stability of the soil was measured as described by Kemper and Rosenau (1996) by single sieve method. In brief; air dried 1-2 mm aggregates were placed in sieves (24 $\mathrm{mesh} / \mathrm{cm}$, hole size $0.26 \mathrm{~mm}$ ) and samples were pre wetted using wetting chamber spraying aerosol. Then those sieves with pre wetted aggregates were place in the sieving equipment which provided a stroke length of $1.3 \mathrm{~cm}$ to the sieves at a frequency of $35 \mathrm{cycles} / \mathrm{min}$. The amount of aggregates remaining in the sieve at distinct time intervals up to $15 \mathrm{~min}$ was determined by oven drying samples at $105^{\circ} \mathrm{C}$ overnight.

\section{Greenhouse and field experiments}

Based on the initial soil characterization and field observation soil fertility constraints were identified, which is elaborated in results and discussion. A site specific fertilizer recommendation (SSF) formulated in previous study for the same field (Chathurika et al., 2014) was adopted for the present experiment to correct nutrient deficiencies in the soil. Biochar was used as the organic soil amendment to improve both physical and chemical related soil constraints. For the production of biochar sawdust from Alstonia macrophylla was collected from commercial timber mill at Peradeniya. Fresh sawdust was packed in to a stainless steel container which was covered with a lid and combusted in a stove at 400-500 ${ }^{0} \mathrm{C}$ for three and half hour to produce biochar via slow pyrolysis. To correct the poor drainage condition and high clay content rock powder was selected as the soil amendment. Rock powder was collected from commercial metal trading agent. Both biochar and rock powder particles in-between $0.05 \mathrm{~mm}-2 \mathrm{~mm}$ were used for field application.

Treatments were; soil only control (C), SSF (Urea- $325 \mathrm{~kg} / \mathrm{ha}$, TSP- $100 \mathrm{~kg} / \mathrm{ha}, \mathrm{MOP}-50$ $\mathrm{kg} / \mathrm{ha}, \mathrm{S}-5 \mathrm{~kg} / \mathrm{ha}$ and Zn- $2 \mathrm{~kg} / \mathrm{ha}$ ), biochar applied at $5 \mathrm{~g} / \mathrm{kg}$ with SSF (BC+SSF) and rock powder $50 \mathrm{~g} / \mathrm{kg}$ with SSF (RP+SSF). As biochar contained high amount of available K, $6 \%$ of MOP fertilizer was cut down from BC+SSF treatment. Initially treatments were evaluated under controlled environment in greenhouse using maize (Zea mays) variety Sampath (a local hybrid) as the test crop in randomized complete block design with four replicates. Maize seeds were planted in pots (height- $18 \mathrm{~cm}$, diameter- $17 \mathrm{~cm}$ ) and soil moisture was 
maintained close to field capacity. Plants were uprooted and dry matter yield was obtained 72 days after seeding.

The field experiment was conducted using same treatments arranged in randomized complete block design with four replicates in $3.2 \times 3.6$ m plots. To minimize the cost of application of at farmer scale biochar could be applied to individual planting hole (Major, 2010). Therefore, in this experiment both calculated weights of fertilizer and amendments were added to each planting hole for two days before planting. Considering 55,000 planting holes per hectare the calculated rate of application of BC and RP for whole field was 1 t/ha and $10 \mathrm{t} / \mathrm{ha}$ respectively, which were equivalent to the rates applied at greenhouse experiment. Urea was applied as a split application $(75 \mathrm{~kg} / \mathrm{ha}$ as a basal dressing at the planting and rest $250 \mathrm{~kg} / \mathrm{ha}$ as a top dressing one month after planting). Maize variety Sampath was planted in $60 \times 30$ $\mathrm{cm}$ spacing and one plant was maintained in a hill. Other cultural practices were adapted as recommended by the Department of Agriculture (DOA, 2013). The field experiment was conducted for two consecutive seasons; $1^{\text {st }}$ season $\left(2013\right.$ Yala) and $2^{\text {nd }}$ season $(2013 / 2014$ $M a h a$ ). In the $2^{\text {nd }}$ season same amount of amendments were applied as described before.

Nine soil samples were collected from each plot systematically by end of the $1^{\text {st }}$ season and $2^{\text {nd }}$ season close to the plant base avoiding the plants in border rows. Then these samples were mixed and a composite sample was used for soil analyses. Land preparation was performed in the second season taking care of not mixing soils between different plots but enabling soil mixing within the plot. Therefore, another soil sample was collected systematically from each plot after land preparation for the $2^{\text {nd }}$ season (before amendments applied to $2^{\text {nd }}$ season). Soils collected at the end of both seasons and before amendments added in the $2^{\text {nd }}$ season were analyzed for $\mathrm{pH}, \mathrm{EC}, \mathrm{OM}$ content, and CEC. Potentially mineralizable nitrogen, active $\mathrm{C}$ and aggregate stability was measured and LI, CPI and CMI was calculated at the end of $1^{\text {st }}$ and $2^{\text {nd }}$ seasons. Soil bulk density and textural classes were determined at the end of $2^{\text {nd }}$ season. Grain yield was taken at maturity, i.e., 105 days after planting, by harvesting maize cobs avoiding border rows and drying grains first in sun and then in room temperature.

\section{Statistical analysis}

Analysis of Variance (ANOVA) for pH, EC, OM, PMN, POXC, LI, CPI, CMI and yield were performed using the SAS statistical software (SAS 9.1) with two factor factorial for field experiment data. Plant dry weight of the greenhouse experiment, BD and soil texture for field experiment was analysed using one way ANOVA. Normality of data was tested using Shapiro Wilks test from Proc Univariate $(W<0.9)$ and whenever data were not normally distributed, natural $\log$ transformed data were used for analysis to meet the assumption of normality of residuals. Least square means were used to compare mean differences with different treatments with DUNCAN multiple range test.

\section{RESULTS AND DISCUSSION}

\section{Initial soil and amendments properties}

Soil had neutral $\mathrm{pH}$ with lower soil organic matter content and moderate CEC (Table 1). Texture of the soil was sandy clay loam with comparatively high clay content. Soil was deficient for available $\mathrm{NH}_{4}-\mathrm{N}, \mathrm{PO}_{4}^{-3}, \mathrm{Ca}, \mathrm{SO}_{4}{ }^{2-} \mathrm{S}, \mathrm{Zn}$ and $\mathrm{Cu}$; whereas, $\mathrm{K}, \mathrm{Mg}, \mathrm{Mn}$ and $\mathrm{Fe}$ in sufficient concentration (Table 2) according to the optimum concentrations described by 
Portch and Hunter (2002). Therefore, nutrient imbalances, poor nutrient retention as a result of low organic matter content and poor drainage facilitated by high clay content were predicted as the site specific soil fertility constraints. The effects of a balance site specific fertilizer mixture, biochar and rock powder were tested for their effectiveness to rectify the problems.

Biochar used in the study had $11 \%$ of volatile compounds $3 \%$ of ash and $86 \%$ of apparent fixed C content by weight. Apparent fixed carbon content of biochar was $859 \mathrm{~g} / \mathrm{kg}$ (Table 1), which is comparable to values reported previously (Lehmenn et al., 2002; Glaser et al., 2002; Rondon et al., 2007). Biochar had an alkaline $\mathrm{pH}$ and high amount of available K content $(1736 \mathrm{mg} / \mathrm{kg}$ ) was observed for biochar but other tested nutrients were in low concentrations. Rock powder had slightly alkaline $\mathrm{pH}$ (Table 1) and low amount of available nutrients (Table 2).The particle size distribution pattern of biochar and rock powder is given in Fig. 1. Above the mean diameter of $1.5 \mathrm{~mm}$ particle size distribution pattern was similar for both BC and RP.

Table 1. Properties of soil used for the study and properties of two amendments used

\begin{tabular}{|c|c|c|c|}
\hline Parameter & Soil & Biochar & Rock powder \\
\hline $\mathrm{pH}\left(1: 2.5\right.$, soil: $\left.\mathrm{H}_{2} \mathrm{O}\right)$ & $7.1(0.42)$ & $8.7(0.04)$ & $7.8(0.02)$ \\
\hline $\mathrm{CEC}\left(\mathrm{cmol}_{+} \mathrm{kg}^{-1}\right)$ & $16.0(1.40)$ & $46(0.1)$ & 2.8 \\
\hline Clay $(\%)$ & $27(0.81)$ & NA & NA \\
\hline Silt (\%) & $12(0.67)$ & NA & NA \\
\hline Sand $(\%)$ & $61(0.85)$ & NA & NA \\
\hline $\mathrm{OM}(\%)$ & $1.5(0.07)$ & NA & NA \\
\hline $\mathrm{EC}\left(\mathrm{dS} \mathrm{m} \mathrm{m}^{-1}\right)$ & $0.12(0.03)$ & $1.42(0.04)$ & $0.33(0.01)$ \\
\hline Apparent fixed C $(\mathrm{g} / \mathrm{kg})$ & $\mathrm{NA} \dagger$ & $859(64)$ & NA \\
\hline $\mathrm{C}: \mathrm{N}$ ratio & NA & 107 & NA \\
\hline Total N (\%) & NA & $0.8(0.01)$ & NA \\
\hline
\end{tabular}

Table 2. Available nutrients concentrations of soil used for the study and properties of two amendments used

\begin{tabular}{|c|c|c|c|}
\hline \multirow{2}{*}{ Parameter } & \multicolumn{3}{|c|}{ Nutrient concentration $(\mathrm{mg} / \mathrm{kg})$} \\
\hline & Soil & Biochar & Rock powder \\
\hline $\mathrm{NH}_{4}-\mathrm{N}$ & $2(0.57)$ & $2(0.57)$ & $\mathrm{NA}^{\dagger}$ \\
\hline $\mathrm{P}$ & $19(3.81)$ & $19(3.81)$ & $2.1(0.01)$ \\
\hline K & $230(1.29)$ & $1736(1.29)$ & $211(1.4)$ \\
\hline $\mathrm{Ca}$ & $1048(3.70)$ & $1048(3.70)$ & $312(8.5)$ \\
\hline $\mathrm{Mg}$ & $738(18.20)$ & $738(18.20)$ & NA \\
\hline $\mathrm{SO}_{4}^{2-} \mathrm{S}$ & $22(1.31)$ & $22(1.31)$ & NA \\
\hline $\mathrm{Zn}$ & $1.3(0.21)$ & $1.3(0.21)$ & NA \\
\hline $\mathrm{Fe}$ & $35(3.42)$ & $35(3.42)$ & NA \\
\hline Mn & $31(2.89)$ & $31(2.89)$ & NA \\
\hline $\mathrm{Cu}$ & $2.9(0.84)$ & $2.9(0.84)$ & $0.56(0.01)$ \\
\hline
\end{tabular}

* Means of four replicates. Values in parentheses are standard deviations, $\uparrow$ Not analysed 


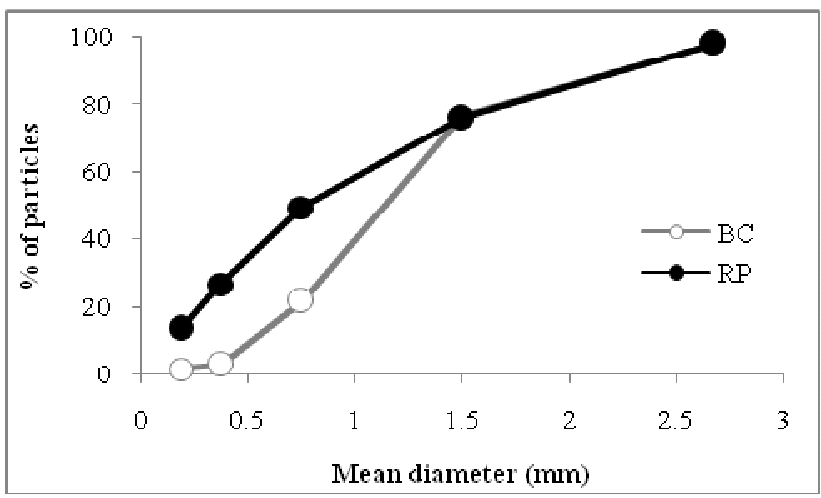

Fig. 1. Particle size distribution of sawdust biochar (BC) and rock powder (RP)

\section{Plant growth for greenhouse experiment}

Application of soil amendments (BC and RP) along with fertilizers significantly increased plant growth compare to the fertilizer only treatment (SFF) in the greenhouse experiment (Fig. 2). Therefore, application of fertilizer with biochar and rock powder amendment did not limit the plant growth in the greenhouse study confirming that selected amendments will not have negative impact on plant growth. Uzoma et al. (2011) conducted a greenhouse experiment using different rates of cow manure biochar and they also found that, biochar application improves plant growth significantly. Silva et al. (2013) found that plant growth significantly increases with application of granitic powder in a greenhouse study.

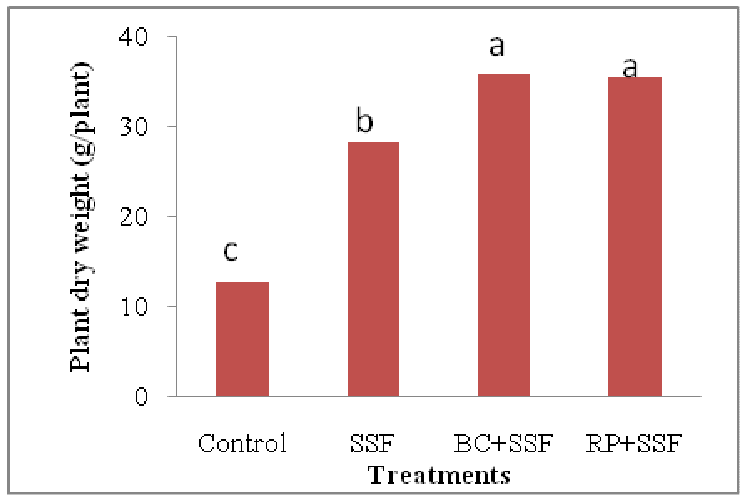

Fig. 2. Plant dry weights at $50 \%$ flowering during greenhouse experiment for different treatments (C- control; SSF -Site specific fertilizer; BC +SSF Biochar with fertilizer; RP+SSF - rock powder with fertilizer). Different letters above bars indicate a significant difference at $P<0.05$. 


\section{Field experiment}

Soil pH, electrical conductivity, organic matter and cation exchange capacity for field experiments

The main effect of treatments were significant but season and interaction of season $\mathrm{x}$ treatment was not significant for soil $\mathrm{pH}(\mathrm{P}<0.05)$. Increase in soil $\mathrm{pH}$ in acidic soils with biochar application had been previously observed (Glaser et al., 2002; Novak et al., 2009; Masulili et al., 2010). However, Van Zwieten et al. (2010) and Busch \& Glaser (2015) did not observe a significant increase in soil $\mathrm{pH}$ with biochar application in alkaline soils.

Table 3. Changes in soil pH, electrical conductivity, organic matter and cation exchange capacity at three stages, 1) End of $1^{\text {st }}$ season, 2) Before amendments apply to $2^{\text {nd }}$ season, 3 ) End of $2^{\text {nd }}$ season

\begin{tabular}{|c|c|c|c|c|c|}
\hline & Treatment $^{\dagger}$ & pH & $\mathrm{EC}(\mu \mathrm{S} / \mathrm{cm})$ & OM (\%) & $\mathrm{CEC}\left(\mathrm{cmol}_{(+)} / \mathbf{k g}\right)$ \\
\hline \multirow{4}{*}{ 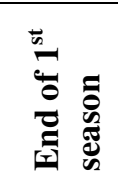 } & $\mathrm{C}$ & $7.3^{\mathrm{a}^{*}}$ & $136^{\mathrm{b}}$ & $1.25^{\mathrm{a}}$ & $16.3^{b}$ \\
\hline & SSF & $7.3^{\mathrm{a}}$ & $153^{\mathrm{ab}}$ & $1.07^{\mathrm{a}}$ & $17.0^{\mathrm{b}}$ \\
\hline & $\mathrm{BC}+\mathrm{SSF}$ & $7.1^{\mathrm{a}}$ & $151^{\mathrm{ab}}$ & $1.29^{\mathrm{a}}$ & $20.5^{\mathrm{a}}$ \\
\hline & $\mathrm{RP}+\mathrm{SSF}$ & $7.2^{\mathrm{a}}$ & $167^{\mathrm{a}}$ & $1.18^{\mathrm{a}}$ & $16.2^{\mathrm{b}}$ \\
\hline \multicolumn{2}{|c|}{ Season mean } & $7.2^{\mathrm{A}}$ & $152^{\mathrm{A}}$ & $1.20^{\mathrm{B}}$ & $17.5^{\mathrm{A}}$ \\
\hline \multirow{4}{*}{ 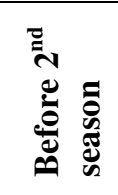 } & $\mathrm{C}$ & $7.3^{\mathrm{a}}$ & $148^{\mathrm{a}}$ & $1.35^{\mathrm{a}}$ & $16.3^{b}$ \\
\hline & SSF & $7.2^{\mathrm{a}}$ & $152^{\mathrm{a}}$ & $1.37^{\mathrm{a}}$ & $16.1^{\mathrm{b}}$ \\
\hline & $\mathrm{BC}+\mathrm{SSF}$ & $7.1^{\mathrm{a}}$ & $154^{\mathrm{a}}$ & $1.44^{\mathrm{a}}$ & $17.8^{\mathrm{a}}$ \\
\hline & $\mathrm{RP}+\mathrm{SSF}$ & $7.2^{\mathrm{a}}$ & $161^{\mathrm{a}}$ & $1.38^{\mathrm{a}}$ & $16.1^{\mathrm{b}}$ \\
\hline \multicolumn{2}{|c|}{ Season mean } & $7.3^{\mathrm{A}}$ & $154^{\mathrm{A}}$ & $1.38^{\mathrm{A}}$ & $16.7^{\mathrm{A}}$ \\
\hline \multirow{4}{*}{ 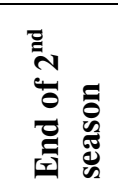 } & $\mathrm{C}$ & $7.3^{\mathrm{a}}$ & $137^{\mathrm{b}}$ & $1.39^{\mathrm{b}}$ & $16.5^{b}$ \\
\hline & SSF & $7.2^{\mathrm{a}}$ & $153^{\mathrm{ab}}$ & $1.38^{\mathrm{b}}$ & $17.0^{\mathrm{b}}$ \\
\hline & $\mathrm{BC}+\mathrm{SSF}$ & $7.1^{\mathrm{a}}$ & $149^{\mathrm{ab}}$ & $1.57^{\mathrm{a}}$ & $20.7^{\mathrm{a}}$ \\
\hline & $\mathrm{RP}+\mathrm{SSF}$ & $7.2^{\mathrm{a}}$ & $167^{\mathrm{a}}$ & $1.38^{\mathrm{b}}$ & $16.4^{\mathrm{b}}$ \\
\hline \multicolumn{2}{|c|}{ Season mean } & $7.2^{\mathrm{A}}$ & $152^{\mathrm{A}}$ & $1.43^{\mathrm{A}}$ & $17.7^{\mathrm{A}}$ \\
\hline & & & & $P$ value & \\
\hline \multicolumn{2}{|c|}{ Treatment } & 0.0162 & 0.0018 & 0.1044 & $<0.0001$ \\
\hline \multicolumn{2}{|l|}{ Season } & 0.1989 & 0.8888 & 0.0005 & 0.0189 \\
\hline \multicolumn{2}{|c|}{ Treatment $\mathrm{x}$ season } & 0.9691 & 0.8987 & 0.8084 & 0.0881 \\
\hline \multicolumn{2}{|l|}{$\mathrm{CV} \%$} & 1.31 & 9.22 & 11.64 & 5.85 \\
\hline
\end{tabular}

Treatment effect was significant $(\mathrm{P}<0.05)$ for the EC. End of the both $1^{\text {st }}$ and $2^{\text {nd }}$ seasons EC was significantly increased with the application of fertilizer, BC and RP (Table 3). Further the highest EC was observed for RP+SSF treatment. EC was not significant among the treatment after mixing the soil within the treatment in the land preparation, before amendments applied in to the $2^{\text {nd }}$ season. As expected application of fertilizer significantly increase the EC in both seasons. A Study conducted by Méndez et al. (2012) found that with 
the application of biochar EC was increase by four fold than the control but they used higher application rates (4 and 8\%) than in the present study. Application of feldspar containing rock powder to the soil is known to significantly increase EC after the fourth harvest of crop (Priyono and Gilkes, 2008).

Soil organic matter contents were significantly different between seasons $(\mathrm{P}<0.05)$ (Table 3$)$. Organic matter content in soils before and after the $2^{\text {nd }}$ season was significantly higher than the end of $1^{\text {st }}$ season. This may be due to addition of crop residue after the $1^{\text {st }}$ season to soil enhancing OM content. However, soil OM content did not increase significantly under BC treatment. Results of the current study contrast with previous findings where biochar addition significantly increased the soil organic $\mathrm{C}$ or soil $\mathrm{OM}$ contents in laboratory incubation (Novak et al., 2009; Masulili et al., 2010; Sukartono et al., 2011) and field studies (Major et al., 2010). As expected RP application did not change the OM content in the soil. The carbon content did not significantly reduce after application of different rates of granitic rock powder to soil which is having high native carbon content (Silva et al., 2013).

Effects of the amendments and the season were significant $(\mathrm{P}<0.05)$ on soil CEC. Application of BC significantly increased the CEC for both first and second seasons (Table 4). Interestingly, after the land preparation even with the mixing amendments in the whole area of the plot biochar showed significant effect on soil CEC (Table 4). Results of the previous studies found that, application of biochar (Masulili et al., 2010; Sukartono et al., 2011) increased CEC significantly. Presence of carboxylic and phenolic functional groups in biochar results in high surface negative charges (Cheng et al., 2006), therefore having a greater ability than other organic matter to absorb cations (Liang et al., 2006). Application of RP did not increase the CEC significantly compared with the un-amended soil, this may be due to the low CEC observed in the RP $\left(2.8 \mathrm{cmol}_{(+)} / \mathrm{kg}\right)$.

\section{Soil potentially mineralizable nitrogen}

Potentially mineralizable $\mathrm{N}$ in the soil reflects the organic matter pools being mineralized and it is determined by anaerobic incubation (Keeney and Bremner, 1996). Main effects of treatment and season was significantly different $(\mathrm{P}<0.05)$.

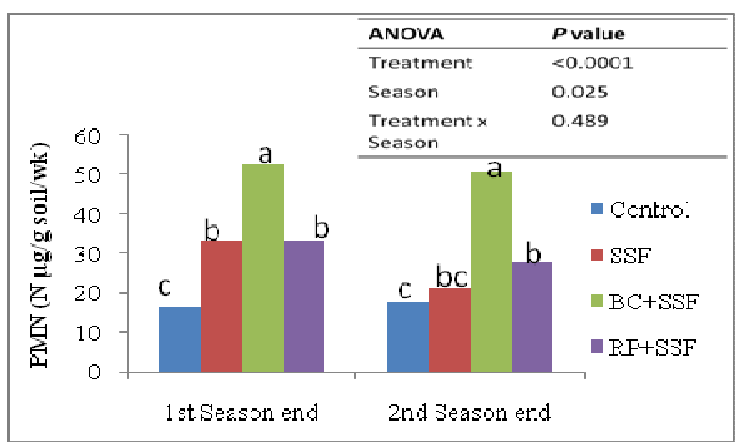

Fig 3. Changes in soil potentially mineralizable nitrogen during end of the first and second seasons for different treatments (C- control; SSF -Site specific fertilizer; BC +SSF -Biochar with fertilizer; RP+SSF - Rock powder with fertilizer). Different letters above bars indicate a significant difference at $\mathbf{P}<\mathbf{0 . 0 5}$. 
However, the interaction effect of treatment $\mathrm{x}$ season was not significant with the added amendments $(\mathrm{P}<0.05)$ for $\mathrm{PMN}$. Application of biochar with fertilizer significantly increases the PMN, $52.21 \mu \mathrm{g} \mathrm{N} / \mathrm{gsoil} / \mathrm{wk}, 50.8 \mu \mathrm{g} \mathrm{N} / \mathrm{g}$ soil/wk after the first and second season respectively (Fig. 3). Therefore, more it can be predicted that more nitrogen is in the labile organic pool in BC amended soil facilitating slow releasing of $\mathrm{N}$ over a longer period of time, which would benefit the crop growth. Previous studies (Chae and Tabatabai, 1986; Jin et al., 2011) have shown that the addition of organic amendments increases the PMN value in soils and the change in PMN depends on both the quality and quantity of organic amendment addition.

\section{Labile carbon and carbon management}

Soil organic carbon has significant impact on soil behaviour and microbial processes but small changes of organic matter are often difficult to measure. It will take many years for contrasting soil management practices to cause quantifiable differences in organic matter (Sikora et al., 1996). However, small changes in labile fractions of soil organic carbon may provide an early indication of soil degradation or improvement in response to management practices. The permanganate oxidizable carbon is an index of soil labile carbon, which is used to explain the potential loss of soil organic carbon (Weil et al., 2003). The carbon management index shows the influence of land use on the total organic carbon levels.

Table 4. Changes in soil permanganate oxidizable carbon (Labile C), carbon pool index, lability index and carbon management index for different treatments

\begin{tabular}{|c|c|c|c|c|c|}
\hline & Treatment $^{\dagger}$ & $\begin{array}{l}\text { POXC (C } \\
\mathrm{mg} / \mathrm{g})\end{array}$ & CPI & $\mathbf{L I}$ & CMI \\
\hline \multirow{4}{*}{ 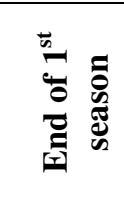 } & $\mathrm{C}$ & $531^{\mathrm{b}^{*}}$ & - & - & - \\
\hline & SFF & $572^{\mathrm{b}}$ & $1.04^{\mathrm{a}}$ & $1.08^{\mathrm{a}}$ & $107.6^{\mathrm{b}}$ \\
\hline & $\mathrm{BC}+\mathrm{SFF}$ & $759^{\mathrm{a}}$ & $1.31^{\mathrm{a}}$ & $1.09^{\mathrm{a}}$ & $142.8^{\mathrm{a}}$ \\
\hline & $\mathrm{RP}+\mathrm{SFF}$ & $580^{\mathrm{b}}$ & $1.13^{\mathrm{a}}$ & $0.95^{\mathrm{a}}$ & $108.1^{\mathrm{b}}$ \\
\hline \multicolumn{2}{|c|}{ Season mean } & $610^{\mathrm{A}}$ & $1.16^{\mathrm{A}}$ & $1.03^{\mathrm{A}}$ & $119^{\mathrm{A}}$ \\
\hline \multirow{4}{*}{ 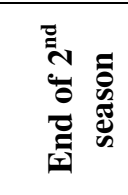 } & $\mathrm{C}$ & $526^{\mathrm{b}}$ & - & - & - \\
\hline & SFF & $509^{\mathrm{b}}$ & $0.99^{b}$ & $0.98^{\mathrm{a}}$ & $96.6^{\mathrm{b}}$ \\
\hline & $\mathrm{BC}+\mathrm{SFF}$ & $676^{\mathrm{a}}$ & $1.13^{\mathrm{a}}$ & $1.15^{\mathrm{a}}$ & $129.6^{\mathrm{a}}$ \\
\hline & $\mathrm{RP}+\mathrm{SFF}$ & $515^{\mathrm{b}}$ & $0.99^{\mathrm{b}}$ & $0.98^{\mathrm{a}}$ & $97.7^{\mathrm{b}}$ \\
\hline \multicolumn{2}{|c|}{ Season mean } & $556^{\mathrm{A}}$ & $1.04^{\mathrm{B}}$ & $1.04^{\mathrm{A}}$ & $108^{\mathrm{A}}$ \\
\hline & & \multicolumn{4}{|c|}{ P value } \\
\hline \multicolumn{2}{|c|}{ Treatment } & $<0.0001$ & 0.0058 & 0.1659 & $<0.0001$ \\
\hline \multicolumn{2}{|c|}{ Season } & 0.0023 & 0.0163 & 0.9259 & 0.0028 \\
\hline \multicolumn{2}{|c|}{ Treatment $\mathrm{x}$ season } & 0.3554 & 0.5008 & 0.5148 & 0.9376 \\
\hline \multicolumn{2}{|l|}{ CV\% } & 7.68 & 10.4 & 14.5 & 7.2 \\
\hline
\end{tabular}

C- control; SSF -Site specific fertilizer; BC +SSF -Biochar with fertilizer; RP+SSF - Rock powder with fertilizer, *Means (of four replicates) within the same column for each parameter followed by the same lower case letters are not significantly different at $\mathrm{P}<0.05$, means within the same column for each season followed by upper case letters are not significantly different at $\mathrm{P}<0.05$

The POXC increased significantly with the added biochar than other treatments in both seasons (Table 4$)$. In the $1^{\text {st }}$ season significantly $(\mathrm{P}<0.05)$ higher $\mathrm{CPI}$ value was observed than the $2^{\text {nd }}$ season. Significantly higher CPI and CMI values were observed for biochar 
applied treatment but the RP application did not affect (Table 4) the CMI or labile carbon pool (POXC) or recalcitrant carbon pool. Therefore, biochar facilitate long-term carbon retention compared to other treatments while maintaining the lability of carbon pool.

\section{Sand silt and clay percentage in the soil and bulk density of the soil}

Sand percentages of $57.5 \%, 57.1 \%, 58.5 \%$, and $60.41 \%$; silt percentages of $8.0 \%, 8.6 \%$, $7.5 \%$ and $7.9 \%$; clay percentages of $27.5 \%, 26.8 \%, 27.0 \%$ and $25.5 \%$ were observed for control, SSF, BC+SSF, RP+SSF, respectively at the end of the $2^{\text {nd }}$ season. Increase of sand $\%$ and decreased of clay \% was observed in the RP amended treatment though these differences were not statistically significant. Bulk density for C, SSF, BC+SSF, and RP+SSF were $1.70 \mathrm{~g} / \mathrm{cm}^{3}, 1.68 \mathrm{~g} / \mathrm{cm}^{3}, 1.65 \mathrm{~g} / \mathrm{cm}^{3}$ and $1.59 \mathrm{~g} / \mathrm{cm}^{3}$ respectively for second season. Bulk density values were not significantly different among the treatments. But there was a slight reduction of bulk density in BC and RP added treatment and further, highest reduction was observed in the RP amended treatment.

\section{Wet aggregate stability}

The results of the aggregate stability of wet sieving analysis for two seasons are given in Fig. 4. The results are expressed as the initial sample remaining in the each sieve after different sieving time. As this is a relative measurement and highest amount of soil retain in the sieve after the longest sieving time are considered as more stable aggregates. Therefore, those aggregates are more resistant to erosion by water.
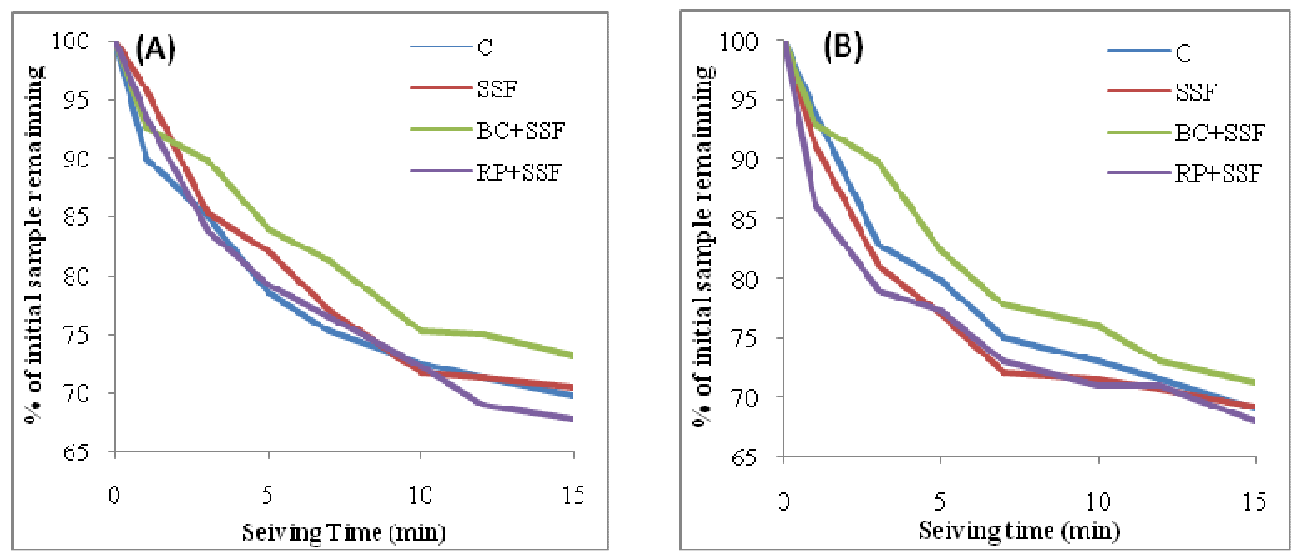

Fig 4. Effect of wet sieving time on the percentage of initial sample remaining in different treatments (C- control; SSF -Site specific fertilizer; BC +SSF Biochar with fertilizer; RP+SSF - Rock powder with fertilizer) for end of the first (A) and second (B) seasons

As in the Fig. 4 there is a slight increase in aggregate stability in biochar with fertilizer treatment than other treatments in both seasons. Application of RP shows the reduction in stable aggregates at $15 \mathrm{~min}$ sieving time in the $1^{\text {st }}$ season. The organic matter application to the soil increase the water stable aggregates as documented by several researchers (Tisdall and Oades, 1983; Mapa and Gunasena, 1995). 


\section{Yield and yield correlation with fertility parameters}

In the $1^{\text {st }}$ season application of rock powder with adequate fertilizers resulted in significantly higher yield compared to other treatments. However, in the $2^{\text {nd }}$ season both amendments added treatments showed higher yield than the SSF (Table 5). Positive effect of biochar application on yield has been reported by several researchers in the field and controlled environment (Glaser et al., 2002; Lehmann et al., 2003; Rondon et al., 2007). Silva et al. (2013) reported that application of granitic rock powder had significantly higher crop productivity than the control treatment. Further, they applied the granitic powder as soil chemical property enhancer. But in this current study rock powder was applied as a soil physical property enhancer and it had positive effect on increasing the yield. Results confirm application of rock powder and biochar were effective in rectifying the soil fertility constraints in the present study.

Table 5. Maize grain yields during end of the first and second seasons for different treatments

\begin{tabular}{|c|c|c|}
\hline \multirow{2}{*}{ Treatment $^{\dagger}$} & \multicolumn{2}{|c|}{ Yield (Mg/ha) } \\
\hline & Yala (2013) & Maha $(2013 / 2014)$ \\
\hline C & $1.63^{\mathrm{c}^{*}}$ & $1.46^{\mathrm{c}}$ \\
\hline SSF & $4.7^{\mathrm{b}}$ & $4.57^{\mathrm{b}}$ \\
\hline $\mathrm{BC}+\mathrm{SSF}$ & $4.99^{\mathrm{ab}}$ & $5.16^{\mathrm{a}}$ \\
\hline $\mathrm{RP}+\mathrm{SSF}$ & $5.26^{\mathrm{a}}$ & $5.13^{\mathrm{a}}$ \\
\hline \multirow[t]{2}{*}{ Season mean } & $4.14^{\mathrm{A}}$ & $4.08^{\mathrm{A}}$ \\
\hline & \multicolumn{2}{|c|}{$P$ value } \\
\hline Treatment & \multicolumn{2}{|c|}{$<0.0001$} \\
\hline Season & \multicolumn{2}{|c|}{0.5885} \\
\hline Treatment $\mathrm{x}$ season & \multicolumn{2}{|c|}{0.7128} \\
\hline CV\% & \multicolumn{2}{|c|}{7.9} \\
\hline
\end{tabular}

C- control; SSF -Site specific fertilizer; BC +SSF -Biochar with fertilizer; RP+SSF - Rock powder with fertilizer, *Means (of four replicates) within the same column for each season followed by the same lower case letters are not significantly different at $\mathrm{P}<0.05$, means within the same row followed by upper case letters are not significantly different at $\mathrm{P}<0.05$

The EC and PMN was had significant positive correlation with the maize grain yield in the $1^{\text {st }}$ season and PMN significantly positively correlated with the maize yield of the $2^{\text {nd }}$ season (Table 6). Increased PMN as a result of application of biochar (Fig. 3) may have contributed to observed yield increment under BC in both seasons (Table 5). Soil $\mathrm{N}$ is a major nutrient that can affect plant growth and performances in various ways. However, large portion of soil $\mathrm{N}$ remains in the stable organic matter pool which is resistant to the microbial degradation and therefore, unavailable to the plant (Jenkinson et al., 1987; Jenkinson and Pary, 1989). Application of biochar has known to increase microbial activities (Thies and Rillig, 2009; Lehmann et al., 2011) therefore it can enhances the mineralization of $\mathrm{N}$ from the organic matter pool and make $\mathrm{N}$ available to plants slowly over the growing season. Applying fertilizers along with BC may have helped to retain nutrients in the labile fraction which slowly decompose and release nutrients. In contrast application of fertilizer alone would flush the system with nutrients increasing their vulnerability to loss in the environment. 
Table 6. Correlation coefficient ( $r$ ) between yield and selected soil properties

\begin{tabular}{lllllllll}
\hline Season & & pH & EC & CEC & OM & PMN & CMI & Clay \\
\hline $\begin{array}{l}\mathbf{1}^{\text {st }} \text { season } \\
\text { end } \\
\mathbf{2}^{\text {nd }} \text { season } \\
\text { end }\end{array}$ & Yield & $\mathrm{NS}^{\dagger}$ & $0.51^{*}$ & NS & NS & $0.65^{*}$ & NS & - \\
\hline
\end{tabular}

${ }^{\star}$ NS not significantly different, * significantly different at $\mathrm{P}<0.05$

\section{CONCLUSIONS}

Soil amendments such as biochar and rock powder improved soil fertility in this tropical Alfisol in DL1b Agro-Ecological region in Sri Lanka. Biochar with fertilizer enhanced soil fertility parameters such as soil OM, CEC, PMN, CMI and wet aggregate stability. Rock powder with fertilizer increased soil EC but had no impact on soil OM, CEC, PMN and CMI. Although rock powder did not yield a significant impact on soil physical properties such as texture and bulk density of the soil the maize yield significantly increased under RP treatment. Biochar resulting in the highest CPI indicates the higher recalcitrant $\mathrm{C}$ in biochar and thereby high potential for retaining carbon in soil for a longer period. It can be concluded that rock powder and biochar along with site specific fertilizer mixture were effective as amendments to rectify the soil fertility constraints (poor drainage and poor nutrient supplying capacity and nutrient deficiencies) in the studied soil. Identification of site specific fertility constraints and correct them by combination of amendments and inorganic fertilizer in nutrient management has beneficial effects on maintaining soil productivity.

\section{ACKNOWLEDGEMENT}

The authors acknowledge the HETC/QIG/W-3/PGIA grant for the financial assistant, Field crop research and development institute, Mahailluppallama for land and facilities provided to conduct field experiments and Rubber research institute, Agalawatta for facilities provided to prepare biochar.

\section{REFERENCES}

Adeoye, K.B., and Mohamed-Saleem, M.A. (1990). Comparison of effects of some tillage methods on soil physical properties and yield of maize and stylo in a degraded ferruginous tropical soil. Soil Till. Res. 18, 63 - 72.

Akinci, I., Cakir, E., Topakci, M., Canakci, M., and O. Inan. (2004). The effect of subsoiling on soil resistance and cotton yield. Soil Till. Res. 77, $203-210$.

Blake, G.R. and Hartge, K.H. (1986). Bulk density. pp. 384-411 In: Klute (Ed.). Methods of soil analysis. Part 1 . Physical and Mineralogical methods. $2^{\text {nd }}$ Edition. American society of Agronomy. Wisconsin, USA.

Busch, D. and Glaser, B. (2015). Stability of co-composted hydrochar and biochar under field conditions in a temperate soil. Soil Use and Management 31, 251 - 258. 
Chae, Y.M and Tabatabai, M.A. (1986). Mineralization of nitrogen in soils amended with organic wastes. J Environ Qual. 15, 193 - 198.

Chathurika, J.A.S., Indraratne, S.P and Dandeniya, W.S. (2014) Site specific fertilizer recommendations for maize (Zea mays) grown in reddish brown earth and reddish brown latasolic soils. Tropical Agricultural Research. 25, 109 - 119.

Cheng, C.H., Lehmann, J., Thies, J.E., Burton, S.D. and Engelhard, M.H. (2006). Oxidation of black carbon by biotic and abiotic processes. Organic Geochemistry 37, 1477 - 1488.

De Silva, G.G.R. and Dassanayake, A.R. (2010). Dry zone soils derived from erosional surfaces. pp. 79-176. In: Mapa, R.B., Somasiri, S. and Dassanayaka, A.R. (Ed.) Soils of the Dry Zone of Sri Lanka Morphology, characterization and Classification. Survodaya Vishva Lekha, Sri Lanka.

Ekwue, E.I., and R.J. Stone. (1995). Organic matter effects on the strength properties of compacted agricultural soils. Trans. ASAE. 38, 357 - 365.

Enders, A., Hanley, K., Whitman, T., Joseph, S. and Lehmann, J. (2012). Characterization of biochar to evaluate recalcitrance and agronomic performance. Bioresources Tec. 114, 664 653.

Gee, G.W. and Dani, O.R. (2000). Particle size analysis. pp. In: D.L J.H. Dane et al., (Ed.) Methods of Soil Analysis, Part 4, Physical Methods: American Society of Agronomy, Madison, Wisconsin, USA.

Gillingham, A.G. and Thorrold, B.S. (2000). A review of New Zealand research measuring phosphorus in runoff from pasture. Journal of Environmental Quality. 29, 88 - 96.

Gillman, G P., Burkett, D. C. Coventry, R J. (2002) Amending highly weathered soils with finely ground basalt rock. Applied Geochemistry. 17, 987 - 1001.

Glaser, B., Lehmann, J. and Zech, W. (2002). Ameliorating physical and chemical properties of highly weathered soils in the tropics with charcoal-a review. Biology and Fertility of Soils. 35, $219-230$.

Jenkinson, D.S., and Parry, L.C. (1989).The nitrogen cycle in the Broad- balk wheat experiment: A model for the turnover of nitrogen through microbial biomass. Soil Biol. Biochem. 21, 535 - 541.

Jenkinson, D.S., Hart, P.B.S., Rayer, J.H. and Parry, L.C. (1987). Modelling the turnover of organic matter in long-term experiments at Rothamsted. INTECOL Bull. 15, 1 - 8.

Jin, V.L, Johnson, M.V, Haney, R.L, Arnold, J.G. (2011). Potential carbon and nitrogen mineralization in soils from a perennial forage production system amended with class B biosolids. Agric Ecosyst Environ. 5, 141 - 461.

Keeney D.R and Bremner J.M. (1996). Comparison and evaluation of laboratory methods of obtaining an index of soil nitrogen availability. Agron J. 58, 498 - 503. 
Keeney, D.R. 1982. Nitrogen management for maximum and minimum pollution. p. 605649. In F.J. Stevenson (ed.) Nitrogen in agricultural soils. Agron. Monogr. 22. ASA, CSSA, and SSSA, Madison, WI.

Kemper, W.D and Rosenau, R.C. (1996). Aggregate stability and size distribution pp 428442. In: D.L J.H. Dane et al., (Ed.) Methods of Soil Analysis, Part 4, Physical Methods: American Society of Agronomy, Soil Science Society of America, Madison, Wisconsin, USA.

Kumaragamage, D. and Indraratne, S.P. (2011). Systematic approach to diagnosing fertility problems in soils of Sri Lanka. Communication in Soil and Plant Analysis. 42, 2699 - 2715.

Lehmann, J., da Silva, P., Steiner, C., Nehls, T., Zech, W. and Glaser, B. (2003). Nutrient availability and leaching in an archaeological Anthrosol and a Ferralsol of the Central Amazon basin: Fertilizer, manure and charcoal amendments. Plant and Soil. 249, 343 - 357.

Lehmann, J., Rillig, M.C., Thies, J., Masiello, C.A., Hockaday, W.C., Crowley, D., (2011). Biochar effects on soil biota e a review. Soil Biology and Biochemistry. 43, 1812 - 1836.

Lehmann, J., Silva J.R, da J.P., Rondon, M., Cravo, M.S., Greenwood, J., Nehls, T., Steiner, C. and Glaser, B. (2002). Slash and char-a feasible alternative for soil fertility management in the central Amazon? Proceedings of the 17th World Congress of Soil Science, Bangkok, Thailand. 449.

Liang, B., Lehmann, J. and Solomon, D. (2006). Black carbon increases cation exchange capacity in soils. Soil Science Society of America Journal. 70, 1719 - 1730.

Liebig, M.A., and Doran, J.W. (1999). Impact of organic production practices on soil quality indicators. J. Environ. Qual. 28, 1601 - 1609.

Major, J. (2010). Guidelines on Practical Aspects of Biochar Application to Field Soil in Various Soil Management Systems, International Biochar Initiatives.

Major, J., Rondon, M., Molina, D., Riha, S.J. and Lehmann, J. (2010). Maize yield and nutrition during 4 years after biochar application to a Colombian savanna oxisol. Plant and Soil.333, $117-128$.

Mapa, R.B. and Gunasena, H.P.M. (1995) Effect of Alley cropping on soil aggregate stability of a tropical Alfisol. Agroforestry Systems. 32, 237 - 245.

Masulili, A., Utomo, W.H. and Syechfani, M.S.(2010). Rice Husk Biochar for rice based cropping system in acid soil 1 . The characteristics of rice husk biochar and its influence on the properties of acid sulfate soils and rice growth in west Kalimantan, Indonesia. Journal of Agricultural Science. 2, 39 - 47.

Méndez, A., Gómez, A., Paz-Ferreiro, J. and Gascó, G. (2012). Effects of sewage sludge biochar on plant metal availability after application to a Mediterranean soil. Chemisphere. 89, $1354-1359$. 
Milton da Veiga, Dalvan José Reinert, José Miguel Reichert and Douglas Rodrigo Kaiser. (2008) Short and long-term effects of tillage systems and nutrient sources on soil physical properties of a southern brazilian hapludox . R. Bras. Ci. Solo. 32,1437 - 1446.

Nelson, D.W. and Sommer L.E. (1996). Total organic carbon and organic matter. pp. 36-404. In: Sparks, D.L. (Ed.) Method of Soil Analysis, Part 3, Chemical Methods: American Society of Agronomy, soil science society of America, Madison, Wisconsin, USA.

Novak, J.M., Busscher, W.J., Laird, D.L., Ahmedna, M., Watts, D.W. and Niandou, M.A.S. (2009). Impact of biochar amendment on fertility of a South-eastern Coastal plain soil. Soil Science. 174, 105 - 112.

Oldeman, L.R., (1994). The global extent of soil degradation. pp. 99-118.In: Greenland, D.J., Szabolcs, I. (Eds.), Soil Resilience and Sustainable Land Use. CAB International, Wallingford, Oxon, UK.

Portch, S. and Hunter, A. (2002). A systematic approach to soil fertility evaluation and improvement. (Special publication No. 5) Canpotex limited, Hong Kong.

Priyono, J. and Gilkes, R.J. (2008).High Energy Milling Improves the Effectiveness of Silicate Rock Fertilizers: A Glasshouse Assessment. Communications in Soil Science and Plant Analysis. 39, 358 - 369.

Rondon, M. A., Lehmann, J., Ramirez, J. and Hurtado, M. (2007). Biological nitrogen fixation by common beans (Phaseolus vulgaris L.) increases with bio-char additions. Biology and Fertility of Soils. 43, $699-708$.

Sikora, L.J., V. Yakovchenko, C.A. Cambardella, and J.W. Doran. (1996). Assessing soil quality by testing organic matter. pp. 41-50.In F.R. Magdoff, M.A. Tabatabai, E.A. Hanlon, Jr (eds.). Soil Organic Matter: Analysis and Interpretations. SSSA Spec. Publ. No. 46. Soil Science Society of America, Madison, WI.

Silva, B., Paradelo, R., Va'zquez, N., Garcı'a-Rodeja, E. and Barral, M.T. (2013) Effect of the addition of granitic powder to an acidic soil from Galicia (NW Spain) in comparison with lime. Environ Earth Sci. 68, 429 - 437.

Sukartono, W.H., Utomo, Kusuma, Z and Nugroho, W.H. (2011) Soil fertility status, nutrient uptake, and maize (Zea mays L.) yield following biochar and cattle manure application on sandy soils of Lombok, Indonesia. Journal of Tropical Agriculture. 49, 47 - 52.

Summer, M.E. and Miller, W.P (1996). Cation exchange capacity and exchange coefficient. pp 1201-1229. In: Sparks, D.L. (Ed.) Method of Soil Analysis, Part 3, Chemical Methods: American Society of Agronomy, Soil Science Society of America, Madison, Wisconsin, USA.

Thies, J., Rillig, M.C., (2009). Characteristics of biochar: biological properties. In: Lehmann, J., Josep, S. (Eds.), Biochar for Environmental Management: Science and Technology. Earthscan, London. Tisdall, J.M. and Oades, J.M. (1983). Organic matter and water stable aggregates in soils. J soil science. 33,141 - 163. 
Uzoma K.C., Inoue, M., Andry, H., Fujimaki, H. Zahoor, A. and Ni shihara, E. (2011). Effect of cow manure biochar on maize productivity under sandy soil condition. Soil Use and Management. 27, 205 - 212.

Van Zwieten, L., Kimber, S., Morris, S., Chan, K.Y., Downie, A., Rust, J., Joseph, S. and Cowie, A. (2010). Effects of biochar from slow pyrolysis of paper mill waste on agronomic performance and soil fertility. Plant and Soil. 327, 235 - 246.

Weil, R.R., Islam, K.R., Stine, M.A., Gruver, J.B. and Samson-Liebig, S.E. (2003). Estimating active carbon for soil quality assessment: A simplified method for laboratory and field use. American Journal of Alternative Agriculture. 18, 3 - 17. 